\title{
骨肉腫の臨床所見の加齢変化
}

\author{
長崎大学医学部整形外科 \\ 奥 平毅・平 野徹 \\ 吉 田 伍一・岩 崎 勝 郎
}

\section{Age-related Changes of Clinico-radiological Findings in Osteosarcoma}

by

\author{
Tsuyoshi Okudaira, Toru Hirano, Goichi Yoshida \\ and Katsuro Iwasaki
}

Department of Orthopaedic Surgery, Nagasaki University School of Medicine, Nagasaki, Japan

In order to investigate age-related changes in clinico-radiological findings of osteosarcoma, we divided 34 patients into the following 3 groups according to their age : Group $1 ; 16$ patients less than 18 years, Group $2 ; 11$ patients from 19 to 49 years and Group $3 ; 7$ patients more than 50 years.

The values of serum alkaline phosphatase in Group 1,2 and 3 were $532 \pm 355,740 \pm 709$ and 344 \pm 198 , respectively. Statistical analysis disclosed a significant decrese of the value in Group 3 . The ratio of sclerotic and mixed types in radiographic appearances of the tumors was $87.5 \%, 63.7 \%$ and $57.2 \%$ in Group 1,2 and 3, respectively. The typical periosteal reactions like Codman's triangle and spicula were observed frequently in Group 1,2 and 3 in that order.

This study suggested that clinico-radiographic appearances of osteosarcoma in elderly patients differed from those in younger subjects in regard to their capability for tumoral and periosteal bone formation.

Key words : Osteosacroma (骨肉腫), Age-related changes (年齢変化), Serum alkaline phosphatase (血清アルカリフォスファターゼ), Neoplastic bone formation (腫瘍性骨形成), Periosteal reaction（骨膜反応）

は じめ に

骨肉腫は，ほとんどが思春期に集中的に発生する。 しかし，その年齢分布は広く，稀ではあるが壮年期か ら老年期にもみとめられている(12)314. これまで骨肉 腫発生年齢の違いによって, どのようにその病状が異 なるか十分に検討されていない"1). そこで, 本研究は, 骨肉腫発生年齢の違いによる臨床的特徴を明らかにす る目的で行った.

\section{対照および方法}

1980 年以降当教室で治療した長管骨発生の骨肉腫
34 齢を対象にした. それらの発生部位は大腿骨 26 例, 脛骨 6 例，上腕骨 2 例および鎖骨 1 例であった。 それ らを病理診断確定時の年齢によって以下の 3 群に分け た.すなわち, Group 1:18 歳以下の若年発生骨肉 腫 16 例, Group 2:19 歳から 49 歳の青・壮年発生 骨肉腫 11 例および group $3: 50$ 歳以上の高年発生骨 肉腫 7 例とした. 年齢発生骨肉腫の臨床的特徴を明ら かにするため, まず開始前の血清アルカリフォスファ ターゼ值（正常值；88-277 国際単位）を調へ，各 Group 別の平均値を求めた。 つぎにX 線学的に, 腫 瘍陰影を硬化型, 混合型および溶骨型に分けた（図 1 ). また骨膜反応の有無についても観察した。 そして各群 

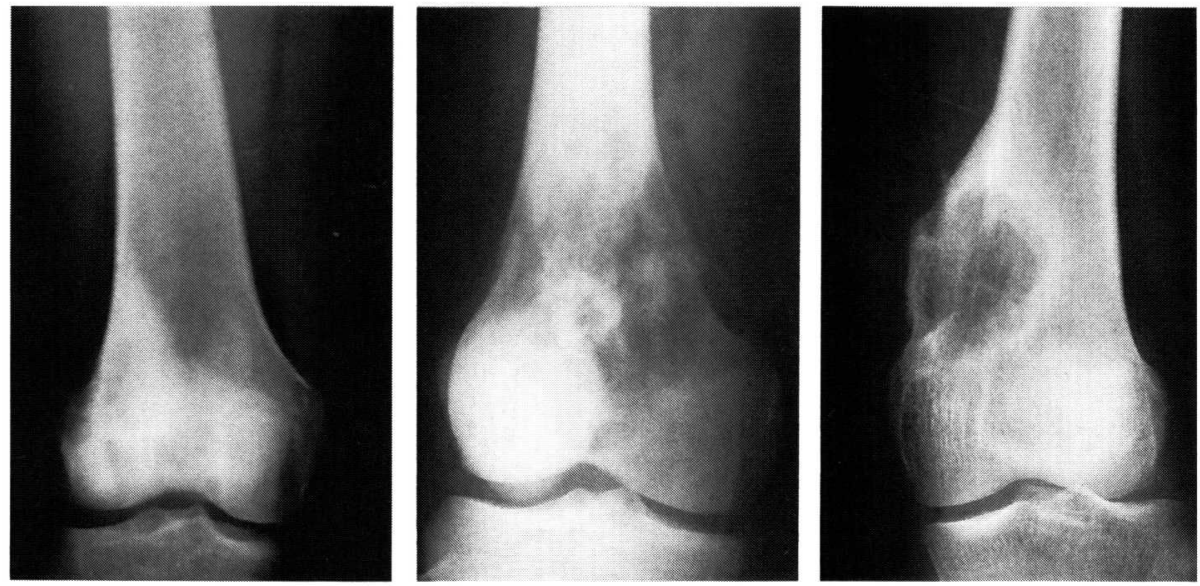

図1 腫瘍陰影のX線分類. 硬化型（左）, 混合型（中央）および溶骨型（右）.

におけるそれらの出現頻度を比較した. 統計学的検定 は student's t-test および分散分析を用い， $\mathrm{p}<0.05$ を 有意差ありとした.

\section{結果}

平均血清アルカリフォスファターゼ值は, Group 1 が $535 \pm 355$ 単位, Group 2 が $740 \pm 709$ 単位㧍よび Group 3 が $344 \pm 198$ 単位と高秢群で有意に減少して いた. 特に高年発生の Group 3 では 7 例中 4 例が正 常值を示していた。

X線学的な腫場陰影は，高齢化するほど硬化型が減 少し溶骨型が増加していた（表 1)。Codman 三角や スピクラなどの骨膜反応は, Group 1 と Group 2 が 81.3\%と 36.4\%であったのに対して, Group 3 ではス ピラクが認められたものは 1 例 $14.3 \%$ けけで, Codmann 三角を形成したものはなかた.

\section{考察}

悪性腫瘍の発生年齢が小児期から壮・老年期まで広 く分布しているものでは, 白血病や横紋筋肉腫などの ように発生年齢の違いによって臨床病理学的に差が認 められている.

骨肉腫もほとんどが思春期に発生するが，その年齢 分布は広く, 稀ではあるが壮年期から老年期にも発生

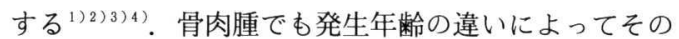
病像に差のあることが推察されるが，この点について の検討はほとんどなされていなかった，本研究では， 発生年齢が若年から高年になるにつれて, 骨芽細胞活
表 1 各グループにおけるX線分類の占める割合 (\%).

\begin{tabular}{c|c|c|c}
\hline \hline グループ & 硬化型 & 混合型 & 溶骨型 \\
\hline 1 & 37.5 & 50.0 & 12.5 \\
2 & 18.2 & 45.5 & 36.3 \\
3 & 14.2 & 42.9 & 42.9 \\
\hline
\end{tabular}

性の指標である血清アルカリフォスファターゼ值上昇 の程度は減少した．さらに，X線学的に腫瘍陰影の主 体は加齢にともなって硬化型から溶骨型へ変化した, Huvos $\mathrm{AG}^{1)}$ は，高齢者の骨肉腫では溶骨型が主体で あることを指摘しており，本研究における高齢者の所 見は同様の結果であった。これらのことは，若年発生 ほど骨肉腫が骨形成能に豊むことを示唆していた，実 際，中敬彦ら ${ }^{2)}$ は，高㱓者の骨肉腫之骨 $\mathrm{MFH}$ を病理 学的に比較し, 高齢者では骨形成が低下し骨 MFH 類 似の所見を示すものが多いことを指摘している．また， 骨膜反応の出現頻度も加齢にもなって減少していたが, これは生体の膜性骨形成能を反映したものであろう。

以上，高柃者の骨肉腫では腫瘍性於よび反応性骨形 成ともに低下していることが分かった．臨床的に，高 榆者の骨肉腫は溶骨型を示すむのが多く骨膜反応む乏 しいことなど骨肉腫としての特徴に欠けるものが多い ことから，転移性骨腫瘍との鑑別が重要である.

$$
\text { ま と め }
$$

1. 骨肉腫発生年齢の違いによる臨床所見の差を検 討した。

2.このため, 骨肉腫 34 例を年齢別に以下の 3 群, 
すなわち Group 1:18 歳以下の若年発生 16 例, Group 2:19 歳から 49 歳の青・壮年発生 11 例およ び Group $3: 50$ 歳以上の高年発生 7 例に分け, 血清 アルフォス值やX線所見などを比較した。

3. 加齢にともなって, 血清アルフォス値は有意に 低下し, 腫瘍陰影は硬化型は減少し溶骨型か増加した。 さらに, Codman 三角やスピクラなどの骨膜反応の 出現頻度は低下した。

4. 以上, 高㱓者の骨肉腫は腫瘍性骨形成と膜性骨 形成いずれも低下していることが示唆された。

\section{参考 文 献}

1) Huvos A. G. : Osteogenic sarcoma of bones and soft tissues in older parsons. A clinicopathological analysis of 117 patients older than 60 years. Cancer $57: 1442$ $1449,1986$.

2）中敬彦ほか：骨肉腫と悪性線維性組織球腫：40 歳以 上の中高年発生例に関する臨床病理学的解析. 日整会誌 68(6) : S887, 1994.

3）中村紳一郎ほか：40 歳以上発生の骨肉腫症例の検討. 日整会誌, 68(6) : S885, 1994.

4) 竹山信成ほか：40 歳以上の骨肉腫の症例の検討. 日整 会誌, 68(6) : S886, 1994. 